\title{
Sustainable Water Security Based on the SDG Framework: A Case Study of the 2019 Metro Manila Water Crisis
}

\author{
Halim Lee ${ }^{1}$, Jaewon Son ${ }^{2} \oplus$, Dayoon Joo ${ }^{3}$, Jinhyeok Ha ${ }^{4}\left(\mathbb{D}\right.$, Seongreal Yun ${ }^{5}$, Chul-Hee Lim ${ }^{6} \oplus$ \\ and Woo-Kyun Lee ${ }^{1, *}$ \\ 1 Department of Environmental Science and Ecological Engineering, Korea University, Seoul 02841, Korea; \\ halimlee@korea.ac.kr \\ 2 Graduate School of International Studies, Korea University, Seoul 02841, Korea; jaewon_son@korea.ac.kr \\ 3 Department of International Commerce and Department of Political Science and International Relations, \\ Yonsei University, Seoul 03722, Korea; dayoonjoo@yonsei.ac.kr \\ 4 Department of International Studies, Yonsei University, Seoul 03722, Korea; glen1221@yonsei.ac.kr \\ 5 Department of Civil and Environmental Engineering, Konkuk University, Seoul 05029, Korea; \\ yunseongreal@gmail.com \\ 6 Institute of Life Science and Natural Resources, Korea University, Seoul 02481, Korea; \\ limpossible@korea.ac.kr \\ * Correspondence: leewk@korea.ac.kr; Tel.: +82-2-3290-3470
}

Received: 26 June 2020; Accepted: 21 August 2020; Published: 24 August 2020

\begin{abstract}
Despite being Asia's fastest-growing economy, as of 2015, the Asian Development Bank (ADB) ranked the Philippines 33rd out of 48 countries in terms of water security. This verifies that economic development does not always lead to better provisions of basic needs. This study attempts to discover the fundamental issues that decrease water security in Metro Manila, the capital region of the Philippines. With El Niño disrupting the optimal weather conditions, Metro Manila is facing the lasting impacts of a water shortage crisis, which is the worst in the past decade. This research inspects the role of climate change in exacerbating El Niño, and its threat to the water security of the developing city. Furthermore, other factors that influence Metro Manila's water security are discussed. Upon establishing a correlation between climate change and El Niño, Metro Manila's general water management strategy is evaluated to better assess the multiple factors that have led to the current water shortage crisis. This paper is intended to recommend necessary and feasible proactive measures that are geared towards water security in Metro Manila, and possibly other cities with similar circumstances.
\end{abstract}

Keywords: water security; Metro Manila; climate change; El Niño; SDGs

\section{Introduction}

Water is a fundamental resource for humans and their well-being. It has been one of the most crucial factors in human development. The recent rapid population growth, economic development, and accumulated disaster risk, along with climate change, have exacerbated water scarcity issues [1]. As widespread urbanization accelerates the demand for water, conflicts between countries over access to water resources have increased significantly. Despite being the fastest-growing economy in Asia as of 2015, the Philippines was ranked 33rd out of 48 countries by the Asian Development Bank (ADB) in terms of water security [2]. This reflects the Philippines' inability to give water security the same level of importance as economic development. Thus, the Philippines' water-related strategies and the main factors in its water security are timely subjects to discuss. 
Doroteo reported that the Philippines has been consistently exposed to high incidents of hazards, such as tropical storms, tsunamis, earthquakes, and droughts, owing to its geographical location [3]. Metro Manila, the capital region of the Philippines, is experiencing the full magnitude of water insecurity, despite it being the most economically developed region within the country. The region has implemented Disaster Risk Reduction Management (DRRM) as a proactive measure for preventing these disasters. However, its DRRM faced several challenges that hindered the system from acting as an effectively proactive measure. The United Nations Office for Disaster Risk Reduction (UNDRR) reported that the biggest limitation to this system was the absence of a powerful governing body that enables more efficient DRRM with administrative and financial powers [4]. Iuchi et al. argue the importance of instituting a governing system that can thoroughly lead all phases of preparedness, mitigation, response, and recovery, to better manage more frequent mega-disasters [5].

Since March 2019, thousands of households in Metro Manila have been reeling from intermittent to no water supply [6]. This severe water crisis has resulted in crop losses in the Philippines, amounting to 464 million Philippine pesos (PHP) [7]. Moreover, approximately 6 million people in the Philippines have suffered from the insufficient water supply. One of the causes that led to this water crisis was the lack of effective and resilient infrastructure, which was exacerbated by the improper management of several projects by Manila Water, a company that provides water treatment, water distribution, sewerage and sanitation services to the east side of Metro Manila. When its project to replenish the water demands of the region was delayed, Manila Water cut the water supply in at least six cities in the east zone of Metro Manila, and seven towns in the nearby Rizal province without appropriate warning [8]. In addition, climate change has significantly impacted the water security of Metro Manila [9]. It has led to irregularities in weather patterns and changes in the natural cycle of the El Niño phenomenon [10]. In the Philippines, El Niño is related to high temperatures and severe dry spells. It is commonly followed by La Niña, which is characterized by heavy rains, severe typhoons and flooding [11]. El Niño refers to warmer than normal sea surface temperatures in the eastern tropical Pacific due to anomalous atmospheric circulation patterns known as the Southern Oscillation [12]. It is a complex and naturally occurring weather pattern that occurs when ocean temperatures in the Pacific Ocean near the equator vary from the norm. Although El Niño is a natural phenomenon, climate change extends and intensifies the El Niño cycle [13]. While it is clear that climate change has led to increased disaster risk in the Philippines, assessing its actual impact on the water crisis could provide reliable information for implementing water-related policies and mitigating climate change.

Despite the numerous pieces of evidence showing that water security research requires a methodological integration across the natural sciences and social sciences/humanities to mutually understand the complex socio-ecological dynamics, the existing research is fragmented across various institutions, locations and practices, not only at the global scale but also at the local scale [14-16]. Employing such interdisciplinary approaches to science will incorporate the enhancement of its legitimacy, the delivery of useful knowledge to society, and the enrichment of the research. A thorough understanding of the links between climate change in aggravating El Niño and the relevant Sustainable Development Goals (SDGs) contributing to water security in Metro Manila is necessary to develop solutions that are based on a sound understanding of both physical and social systems.

This study aims to examine the role of climate change in the current Metro Manila water crisis and identify other factors that have contributed to the crisis. Moreover, it evaluates the current conditions by utilizing the Sustainable Development Goal (SDG) framework through an interlinkage analysis tool, which employs a multi-conceptual approach to realize international development and provide an alternative focus. Thus, this study was conducted with the dual purpose of understanding the main triggers of water security in Metro Manila and identifying effective mechanisms that align with the SDG framework. This study also explores the relationship between climate change and sustainable water security in Metro Manila by focusing on two research statements: (1) climate change plays a significant role in the 2019 Metro Manila water crisis owing to its causal relationship with the El Niño 
phenomenon; (2) Metro Manila's water-related strategies to solve the water shortage issue will be more effective if proactive and participatory approaches are adopted.

\section{Literature Review and Theoretical Framework}

\subsection{Literature Review}

As water resources are affected by climate change, numerous studies have been conducted over the years to establish a relationship between them. Similarly, there are studies dedicated to the efficiency of water-related strategies. However, there are only scattered studies investigating the links between climate change in aggravating El Niño and the relevant SDGs to contribute toward mapping out the water-related strategies integrating both these aspects [14-16]. Therefore, this paper will discuss the compatibility of Metro Manila's water strategies with climate change variations in the environment through interlinkages with related SDGs.

Wang et al. researched the relationship between the high frequencies of El Niño and the global mean temperature (GMT) [17]. Although El Niño is a natural phenomenon, climate change has accelerated its frequency and intensity. Conversely, El Niño exacerbates climate change by releasing heat from the Pacific Ocean into the atmosphere. Furthermore, Wang et al. researched the impact of a $1.5{ }^{\circ} \mathrm{C}$ increase, which is the target set by the UN Intergovernmental Panel on Climate Change (IPCC), on the severity of the El Niño and La Niña phenomena. According to the result, the frequency of extreme El Niño events will double linearly under the $1.5{ }^{\circ} \mathrm{C}$ warming scenario. This increase in frequency could last up to a hundred years, even after the stabilization of the GMT, as shown in Figure 1 [17]. This implies that the next generation will be significantly affected by the rise in average temperatures.

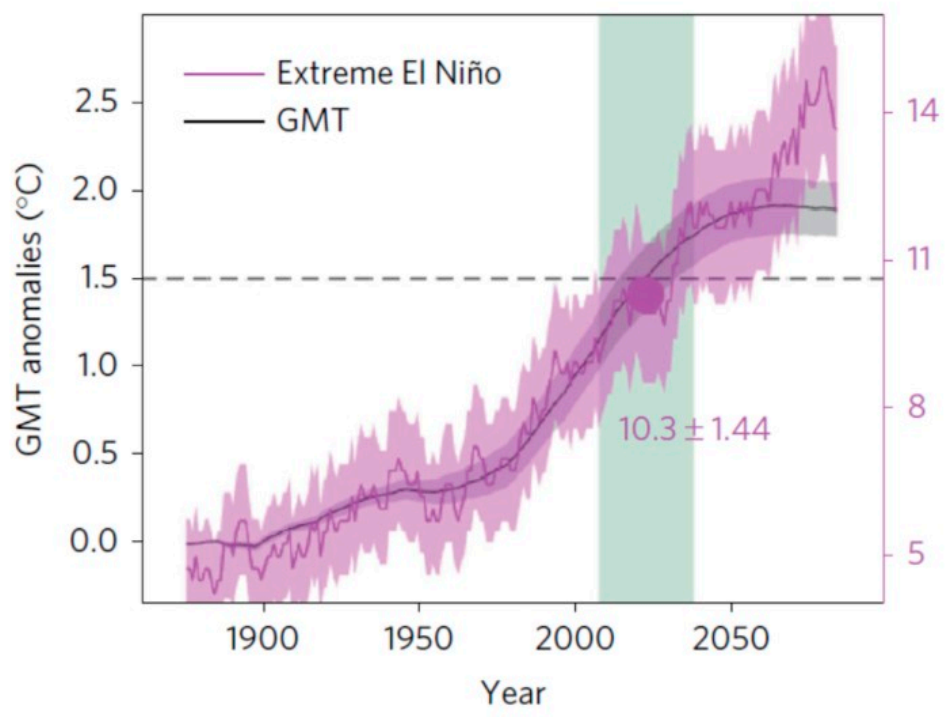

Figure 1. Change in extreme El Niño events and the Global Mean Temperature (GMT) over time. Source: Nature Climate Change [17].

El Niño affects precipitation patterns and contributes to drought. The Food and Agriculture Organization of the United Nations (FAO) focused on the relationship between El Niño and the droughts in Indonesia, and stated that severe droughts are associated with El Niño [18]. Indonesia, similarly to the Philippines, is located in Southeast Asia and is vulnerable to climate change. Therefore, research on the impacts of climate change and El Niño on Indonesia is highly relevant in the case of the Philippines. The key purpose of FAO's research was to determine the relationship between droughts and El Niño. They concentrated on two different relationships: the relationship between El Niño and precipitation, and that between El Niño and the land temperature. They analyzed precipitation 
deficits by comparing El Niño seasons with neutral and La Niña seasons. As a result, they verified that, during the El Niño season, dry periods are 300\% more likely to occur than during the neutral period. On the other hand, it proved that El Niño events do not affect the land temperature at the same magnitude. Furthermore, the likelihood of hot periods increased by $22 \%$ during El Niño, compared to normal conditions and La Niña events. Utilizing this analysis by FAO, we can observe that climate change affects the characteristics and frequency of El Niño, which negatively impacts water security in countries located in tropical regions, such as the Philippines. Considering this as the basic principle, this study identifies Metro Manila's current characteristics and determines if it can achieve sustainable water security.

\subsection{Theoretical Framework: Sustainable Development Goals (SDGs)}

Sustainable development has various definitions, but its most frequently quoted definition is "development that meets the needs of the present generation without compromising the ability of future generations to meet their own needs". This was provided by the World Commission on Environment and Development in 1987 [19]. The SDGs were adopted by the UN General Assembly in 2015, based on the agreement of 193 countries to achieve 17 goals by 2030. The framework incorporates economic, social and environmental aspects for sustainable development to ensure that "no one will be left behind" [20].

Vladimirova investigated SDG 6, which focuses on clean water and sanitation, and found that it is key to achieving the remaining 16 SDGs. Besides meeting the primary purpose of clean water distribution, it also achieves goals that focus on education (SDG 4), human health (SDG 3), economic growth (SDG 8), gender equality (SDG 5), and social justice (SDG 16) [21]. Dr. Geeta Rao Gupta, Deputy Executive Director of the United Nations Children's Fund (UNICEF), once stated that "if we do not achieve Goal 6, the other goals and targets will not be achieved [22]". Thus, researchers deem SDGs a viable framework to evaluate other facets that may contribute to water security. Torres-Slimming et al. highlighted that understanding and responding to local contexts is critical to effectively improve water, sanitation and hygiene in order to contribute to SDG 6 [23]. However, they pointed out that an in-depth understanding of local knowledge, practices and perceptions is often overlooked, which also adds a rationale to our research investigating the local contexts of Metro Manila.

Nerini et al. emphasized the importance of the linkage between climate change impacts and SDGs [16]. They argue that literature which systematically evaluates context-specific synergies and trade-offs between climate action and the SDGs15 are limited. They further highlight that understanding the potential impacts of climate change on all sustainable development domains is necessary to raise awareness and policy support for climate action. Karnib presents a qualitative nexus approach to evaluate the interconnections of the sustainable development targets (SDTs) that directly and indirectly affect one another [24]. He argues that a qualitative SDGs nexus method makes the evaluation of the effects of both direct and indirect interlinkage relations among the SDTs possible. He further points out that the key advantage of this approach is that it generates a science-informed analysis of the interactions across SDTs and SDGs, especially where quantitative interaction-based methods could not be readily applied due to insufficient data.

Despite the inherent interconnection of water security with economic and social conditions, little effort has been made in South Asia to understand their interdependence in terms of resource use and policies [25]. Understanding and managing the links between water, the economy and social conditions is essential for formulating policies to create more resilient and adaptable societies [26]. This paper aims to deepen the understanding and exploration of policy options that minimize trade-offs and maximize synergies among the three sectors. Doing so will support the formulation of cross-sectoral policies and, as a result, suggest ways to build more resilient and adaptable societies in the Philippines. Issues related to water, the economy and social security in Metro Manila, and the associated challenges, will be assessed through a case study. It will discuss how policy and institutional factors lead to the unsustainable use of resources. Moreover, it will analyze the importance of the environmental, social 
and economic factors in managing trade-offs and enhancing synergies-both of which are crucial in achieving the SDGs. This section details a broad framework for better coordination among the three sectors, and the results of the SDG interlinkage analysis are presented in the final section.

\section{Methodology of Research}

\section{Interlinkages Analysis}

This study was conducted with a qualitative approach based on the UN SDGs, through an SDG interlinkages analysis. Figure 2 shows the research flow of this study. To provide more structure to the research, the authors adopted a systematic literature review process as a reference [27]. This process was referenced as it allows the performance of synthesized research on a specific question, using structured, clear and replicable procedures [28]. Furthermore, compared to conventional narrative reviews, it provides more accuracy in the research process [29]. The review was structured into four main phases:

(1) Define the review's motivation and the selection of research questions. During this phase, the authors also selected a theoretical framework, a case study area and a tool to perform the SDGs interlinkage analysis;

(2) Selection of the articles in a structured process involving the inclusion/exclusion of relevant literature;

(3) SDGs interlinkage analysis and visualization process using the tool chosen in the first phase;

(4) Work on the results by synthesizing the findings through a case study summary, answering review questions, and reaching the discussion and conclusion.

Step 1:

Definitions
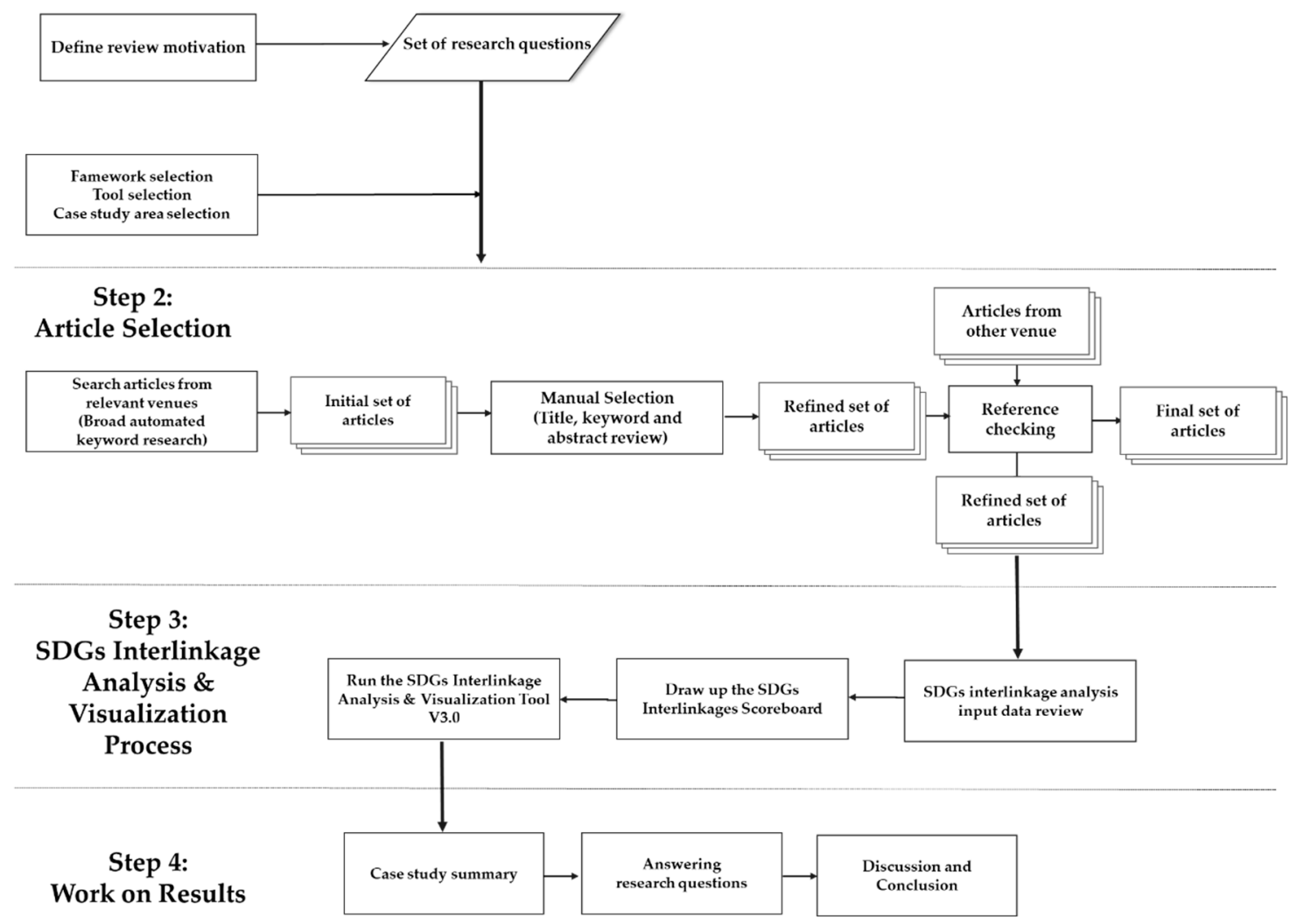

Figure 2. Research flow of this study. 
The SDGs have been deployed to thoroughly discuss the close link between clean water and sanitation (SDG 6) and the other SDGs, especially climate action (SDG 13); industry, innovation and infrastructure (SDG 9); and reduced inequalities (SDG 10). The linkages of SDG 6 with the other SDGs highlights the importance of adopting a holistic approach in tackling water security issues. By applying selected targets and/or indicators of SDGs 6, 9, 10 and 13, this study not only analyzes the link between increased access to water, climate change, infrastructure and reduced inequalities, but also focused on the necessary challenges that the Philippine government will face when improving the sustainability of water resources.

To investigate the relationship of SDG 6 with the other SDGs, interlinkages among SDGs should be evaluated. Using the SDG Interlinkages Analysis \& Visualisation tool V3.0 (Kanagawa, Japonia) the SDG interlinkages were quantified and analyzed. Understanding SDG interlinkages can support policy integration and help minimize conflicts, avoid trade-off and seek synergies to make the achievements inclusive across all 17 SDG areas, specifically SDGs 6, 9, 10 and 13, which are explored in this case study [30]. In order to develop the SDG Interlinkages Analysis \& Visualisation tool V3.0, Zhou and Moinuddin identified the indicators with verifiable data, and mapped them with the SDG targets [31]. They collected time-series data (2001-2014) of the indicators for 27 countries, including the Philippines. They used the results from these two processes for the quantification of the identified interlinkages, based on the correlation analysis of corresponding indicators using their time-series data. After this, a quantified country-specific network of the interlinkages between SDG targets was constructed for the Philippines.

In the visualization tool, the indicators are identified using the official indicators that are enlisted in the Global indicator framework for the Sustainable Development Goals and Targets of the 2030 Agenda for Sustainable Development [32]. A set of indicators corresponding to 113 targets were used for the SDG Interlinkages Analysis \& Visualisation Tool based on the data availability. Time-series data running from 1990 to 2019 for each of the indicators was collected from publicly available and internationally recognized sources. They used the UN Statistics Division's SDG Indicators Global Database [33] as a primary data source, and some additional data was collected from the World Bank SDGs database [34]. When specific data or indicators were not available, time-series data for each indicator was collected from publicly available sources, including the World Bank and various United Nations agencies as shown in Table 1. To create a complete time series, a statistical method based on the Compound Annual Growth Rate (CAGR10) was used to fill in the gaps for particular indicators, based on which a complete time-series data set for all the 51 indicators was prepared [31].

'Interlinkages' can refer to those between goals, between a goal and relevant targets, or between targets. Interlinkages encompass direct relations between two targets or indirect relations which bridge two targets via a third target or more intermediate ones. Furthermore, interlinkages can be defined by their causal relationship, or by other types of relations. For the SDG Interlinkages Analysis \& Visualisation Tool, interlinkages were defined as direct causal relations between the targets. Causal links were quantified based on the correlation analysis of the country-specific time-series data of the indicators, corresponding to the relevant targets. The correlation coefficients, ranging between -1 and 1 , indicated a linear relationship between each pair of targets. Positive coefficients (e.g., 0.9) represent positive linear relations, and negative coefficients (e.g., -0.2$)$ represent negative linear relations. Coefficients with larger absolute values (e.g., 0.9 with an absolute value of 0.9 ) exhibit stronger linear relationships between two targets, and those with smaller absolute values (e.g., -0.2 with the absolute value of 0.2 ) exhibit weaker linear relationships. 
Table 1. The input data used for the SDG Interlinkages Analysis.

\begin{tabular}{|c|c|c|c|}
\hline Target & Indicator & Description & Data Source \\
\hline 6.2 & 6.2 .1 & $\begin{array}{l}\text { Proportion of population practicing } \\
\text { open defecation, by urban/rural (\%) }\end{array}$ & $\begin{array}{l}\text { WHO/UNICEF Joint Monitoring } \\
\text { Programme for Water Supply, } \\
\text { Sanitation and Hygiene (2017) }\end{array}$ \\
\hline 6.6 & 6.6 .1 & $\begin{array}{l}\text { Waterbody extent (permanent and } \\
\text { maybe permanent) }(\% \text { of total } \\
\text { land area) }\end{array}$ & $\begin{array}{l}\text { Global Surface Water Explorer } \\
\text { extraction for UN Environment }\end{array}$ \\
\hline $6 . \mathrm{a}$ & 6.a.1 & $\begin{array}{l}\text { Total official development assistance } \\
\text { (gross disbursement) for water } \\
\text { supply and sanitation, by recipient } \\
\text { countries (millions of constant } 2016 \\
\text { United States dollars) }\end{array}$ & $\begin{array}{c}\text { Creditor Reporting System (CRS) } \\
\text { database, 2018, The Organisation for } \\
\text { Economic Co-operation and } \\
\text { Development (OECD) }\end{array}$ \\
\hline 9.1 & 9.1 .2 & $\begin{array}{l}\text { Passenger volume (passenger } \\
\text { kilometres), by mode of transport }\end{array}$ & $\begin{array}{c}\text { The International Transport Forum at } \\
\text { the OECD (ITF-OECD) }\end{array}$ \\
\hline 9.2 & 9.2 .1 & $\begin{array}{l}\text { Manufacturing value added as a } \\
\text { proportion of GDP }(\%)\end{array}$ & $\begin{array}{l}\text { UNIDO MVA } 2019 \text { Database. } \\
\text { Available at https://stat.unido.org }\end{array}$ \\
\hline 9.3 & 9.3 .1 & $\begin{array}{l}\text { Proportion of small-scale industries } \\
\text { in total industry value added (\%) }\end{array}$ & $\begin{array}{l}\text { Annual Survey of Philippine } \\
\text { Business and Industry (ASPBI), } \\
\text { Philippine Statistics Authority }\end{array}$ \\
\hline 9.4 & 9.4 .1 & $\begin{array}{l}\text { Carbon dioxide emissions per unit of } \\
\text { manufacturing value added } \\
\text { (kilogrammes of } \mathrm{CO}_{2} \text { per constant } \\
2010 \text { United States dollars) }\end{array}$ & $\begin{array}{c}\text { UNIDO MVA } 2019 \text { Database. } \\
\text { Available at https://stat.unido.org. } \\
\text { IEA (2018), } \mathrm{CO}_{2} \text { Emissions from Fuel } \\
\text { Combustion. } \\
\text { https://www.iea.org/statistics }\end{array}$ \\
\hline 9.5 & 9.5 .1 & $\begin{array}{c}\text { Research and development } \\
\text { expenditure as a proportion of } \\
\text { GDP }(\%)\end{array}$ & $\begin{array}{l}\text { UNESCO Institute for Statistics (UIS) } \\
\text { Survey on Research and } \\
\text { Experimental Development Statistics }\end{array}$ \\
\hline 9.a & 9.a.1 & $\begin{array}{l}\text { Total official flows for infrastructure, } \\
\text { by recipient countries (millions of } \\
\text { constant } 2016 \text { United States dollars) }\end{array}$ & $\begin{array}{l}\text { Creditor Reporting System (CRS) } \\
\text { database, 2018, The Organisation for } \\
\text { Economic Co-operation and } \\
\text { Development (OECD) }\end{array}$ \\
\hline $9 . b$ & 9.b.1 & $\begin{array}{l}\text { Proportion of medium and high-tech } \\
\text { industry value added in total value } \\
\text { added (\%) }\end{array}$ & $\begin{array}{l}\text { UNIDO CIP } 2018 \text { Database. } \\
\text { Available at https://stat.unido.org. }\end{array}$ \\
\hline 9.c & 9.c.1 & $\begin{array}{l}\text { Proportion of population covered by } \\
\text { a mobile network, by technology (\%) }\end{array}$ & ITU estimate \\
\hline 10.4 & 10.4 .1 & $\begin{array}{c}\text { Labour share of GDP, comprising } \\
\text { wages and social protection } \\
\text { transfers }(\%)\end{array}$ & ILOSTAT—SNA—National Accounts \\
\hline 10.5 & 10.5.1 & $\begin{array}{l}\text { Regulatory Tier } 1 \text { capital to } \\
\text { risk-weighted assets }(\%)\end{array}$ & http://data.imf.org/FSI \\
\hline 10.6 & 10.6.1 & $\begin{array}{l}\text { Proportion of members of } \\
\text { developing countries in international } \\
\text { organizations, by organization (\%) }\end{array}$ & WTO Annual Report 2015 \\
\hline 10.a & 10.a.1 & $\begin{array}{l}\text { Tariff rate, applied, weighted mean, } \\
\text { all products }(\%)\end{array}$ & World Development Indicators \\
\hline $10 . b$ & 10.b.1 & $\begin{array}{l}\text { Total assistance for development, by } \\
\text { recipient countries (millions of } \\
\text { current United States dollars) }\end{array}$ & $\begin{array}{c}\text { DAC Statistics database, 2018, } \\
\text { The Organisation for Economic } \\
\text { Co-operation and } \\
\text { Development (OECD) }\end{array}$ \\
\hline 10.c & 10.c.1 & $\begin{array}{c}\text { Remittance costs as a proportion of } \\
\text { the amount remitted (\%) }\end{array}$ & $\begin{array}{l}\text { World Development Indicators } \\
\text { database, World Bank }\end{array}$ \\
\hline
\end{tabular}




\section{Results}

\subsection{SDGs Interlinkages Analysis}

Figure 3 shows the linkages among the targets within SDGs 9, 10, 13 and 6 [30]. Each node represents one SDG target, and each line with an arrow between two nodes represents a linkage between the two targets. Black and red lines represent positive and negative linkages, respectively. In addition, a dotted line implies that indicator-level data is not available for the relevant targets.

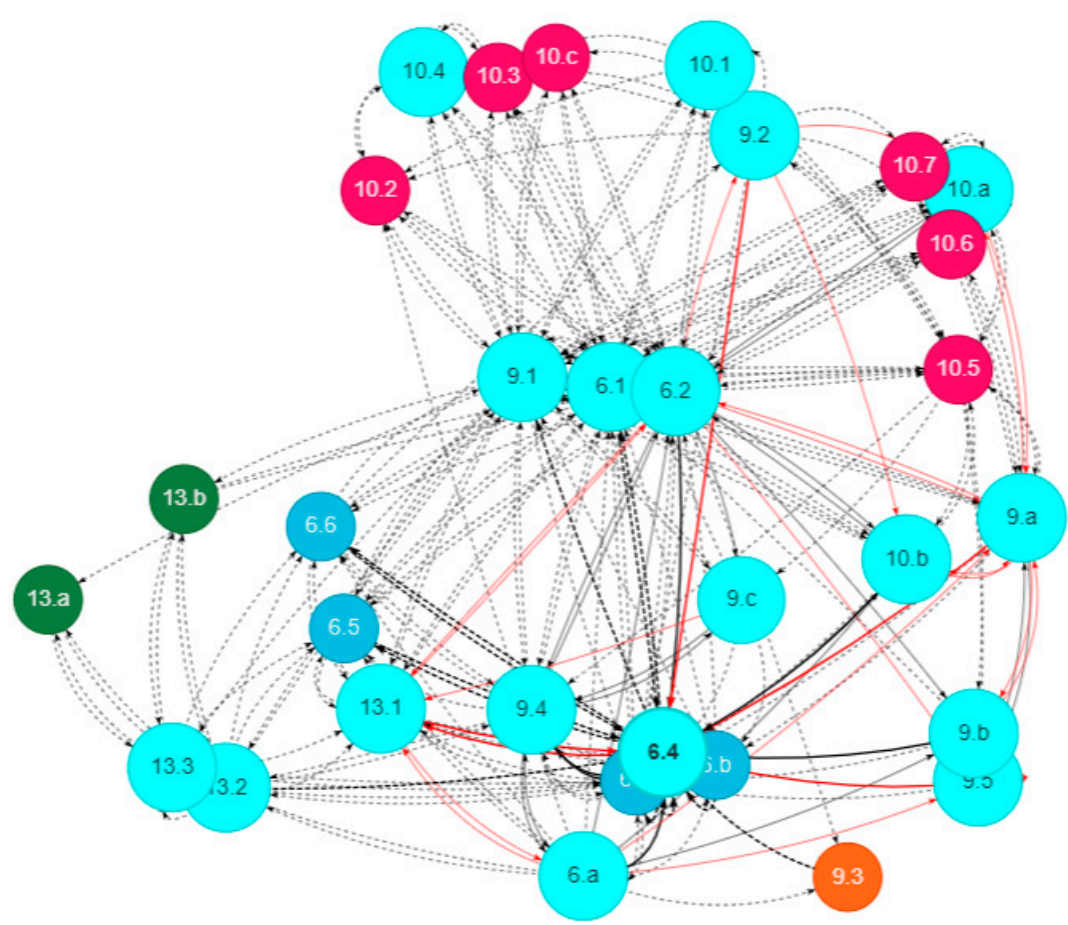

Figure 3. SDGs Interlinkages Analysis of Metro Manila, Philippines. Source: Author's elaboration using the SDG Interlinkages Analysis \& Visualisation Tool [30]. https://sdginterlinkages.iges.jp/ visualisationtool.html.

Several targets of SDG 6 are related to those of SDGs 9, 10 and 13. For example, SDG target 6.6, which focuses on protecting and restoring water-related ecosystems, is linked to SDG target 9.4, which explores upgrading infrastructure and retrofitting industries to make them sustainable, and to SDG target 13.3, which focuses on improving education, raising awareness, and increasing the human and institutional capacity to achieve climate change mitigation, adaptation, impact reduction, and early warnings. Table 2 shows the overall result of the SDGs Interlinkages Analysis, which was produced using the SDG Interlinkages Analysis \& Visualisation Tool. It shows the specific targets of SDGs 9, 10 and 13 that have direct causal relations with SDG 6. 
Table 2. Targets with direct causal relations to SDG 6 .

\begin{tabular}{|c|c|c|}
\hline SDG 6 Target & Related SDG Target & $\begin{array}{l}\text { Correlation } \\
\text { Coefficient }\end{array}$ \\
\hline $\begin{array}{l}\text { 6.1 Safe and affordable drinking } \\
\text { water for all }\end{array}$ & $\begin{array}{l}\text { 9.c Significantly increase access to ICT and strive to provide } \\
\text { universal and affordable access to internet in LDCs by } 2020\end{array}$ & 0.955 \\
\hline \multirow{3}{*}{$\begin{array}{l}\text { 6.2 End open defecation and } \\
\text { provide access to sanitation } \\
\text { and hygiene }\end{array}$} & $\begin{array}{l}\text { 9.c Significantly increase access to ICT and strive to provide } \\
\text { universal and affordable access to internet in LDCs by } 2020\end{array}$ & 0.955 \\
\hline & $\begin{array}{l}9.4 \text { Upgrade infrastructure and retrofit industries to make } \\
\text { them sustainable, with increased resource-use efficiency and } \\
\text { greater adoption of clean and environmentally sound } \\
\text { technologies and industrial processes, with all countries taking } \\
\text { action in accordance with their respective capabilities }\end{array}$ & 0.94 \\
\hline & $\begin{array}{l}\text { 10.b Encourage official development assistance and financial } \\
\text { flows, including foreign direct investment, to States where the } \\
\text { need is greatest, in particular least developed countries, } \\
\text { African countries, small island developing States and } \\
\text { landlocked developing countries, in accordance with their } \\
\text { national plans and programmes }\end{array}$ & 0.802 \\
\hline \multirow{4}{*}{$\begin{array}{l}\text { 6.6 End open defecation and } \\
\text { provide access to sanitation } \\
\text { and hygiene }\end{array}$} & $\begin{array}{l}\text { 9.c Significantly increase access to ICT and strive to provide } \\
\text { universal and affordable access to internet in LDCs by } 2020\end{array}$ & 0.926 \\
\hline & $\begin{array}{l}\text { 9.2 Promote inclusive and sustainable industrialization and, by } \\
\text { 2030, significantly raise industry's share of employment and } \\
\text { gross domestic product, in line with national circumstances, } \\
\text { and double its share in least developed countries }\end{array}$ & -0.792 \\
\hline & $\begin{array}{l}9.3 \text { Increase the access of small-scale industrial and other } \\
\text { enterprises, in particular in developing countries, to financial } \\
\text { services, including affordable credit, and their integration into } \\
\text { value chains and markets }\end{array}$ & -0.971 \\
\hline & $\begin{array}{l}9.4 \text { Upgrade infrastructure and retrofit industries to make } \\
\text { them sustainable, with increased resource-use efficiency and } \\
\text { greater adoption of clean and environmentally sound } \\
\text { technologies and industrial processes, with all countries taking } \\
\text { action in accordance with their respective capabilities }\end{array}$ & 0.949 \\
\hline \multirow{4}{*}{$\begin{array}{l}\text { 6.a Protect and restore } \\
\text { water-related ecosystems, } \\
\text { including mountains, forests, } \\
\text { wetlands, rivers, aquifers, } \\
\text { and lakes }\end{array}$} & $\begin{array}{l}\text { 9.b Support domestic technology development, research and } \\
\text { innovation in developing countries, including by ensuring a } \\
\text { conducive policy environment for, inter alia, industrial } \\
\text { diversification and value addition to commodities }\end{array}$ & 0.189 \\
\hline & $\begin{array}{l}9.4 \text { Upgrade infrastructure and retrofit industries to make } \\
\text { them sustainable, with increased resource-use efficiency and } \\
\text { greater adoption of clean and environmentally sound } \\
\text { technologies and industrial processes, with all countries taking } \\
\text { action in accordance with their respective capabilities }\end{array}$ & 0.247 \\
\hline & $\begin{array}{c}\text { 10.b Encourage official development assistance and financial } \\
\text { flows, including foreign direct investment, to States where the } \\
\text { need is greatest, in particular least developed countries, } \\
\text { African countries, small island developing States and } \\
\text { landlocked developing countries, in accordance with their } \\
\text { national plans and programmes }\end{array}$ & 0.159 \\
\hline & $\begin{array}{l}\text { 10.6 Ensure enhanced representation and voice for developing } \\
\text { countries in decision-making in global international economic } \\
\text { and financial institutions in order to deliver more effective, } \\
\text { credible, accountable and legitimate institutions }\end{array}$ & -0.376 \\
\hline
\end{tabular}

\subsection{Scoreboard for Interlinkages between SDG 6 and Other SDGs}

Interconnecting SDG 6 to the related SDGs requires a major shift in the decision-making process towards adopting a holistic view, developing institutional mechanisms to coordinate the actions of diverse actors, and strengthening complementarities and synergies among the three sectors with SDG 6 [35]. Figure 4 presents a general overview of the relations between SDG 6 and other SDGs in Metro Manila by integrating policies and strategies in these sectors and supporting the move from 
a sectoral to a holistic approach. The key elements of this approach are strengthening cross-sectoral coordination, harmonizing public policies, aligning cross-sectoral strategies and incentive structures, strengthening regulation, and facilitating the use of interconnected investment and technologies in Metro Manila.

SDG6 Interlinkages with other SDGs scoreboard

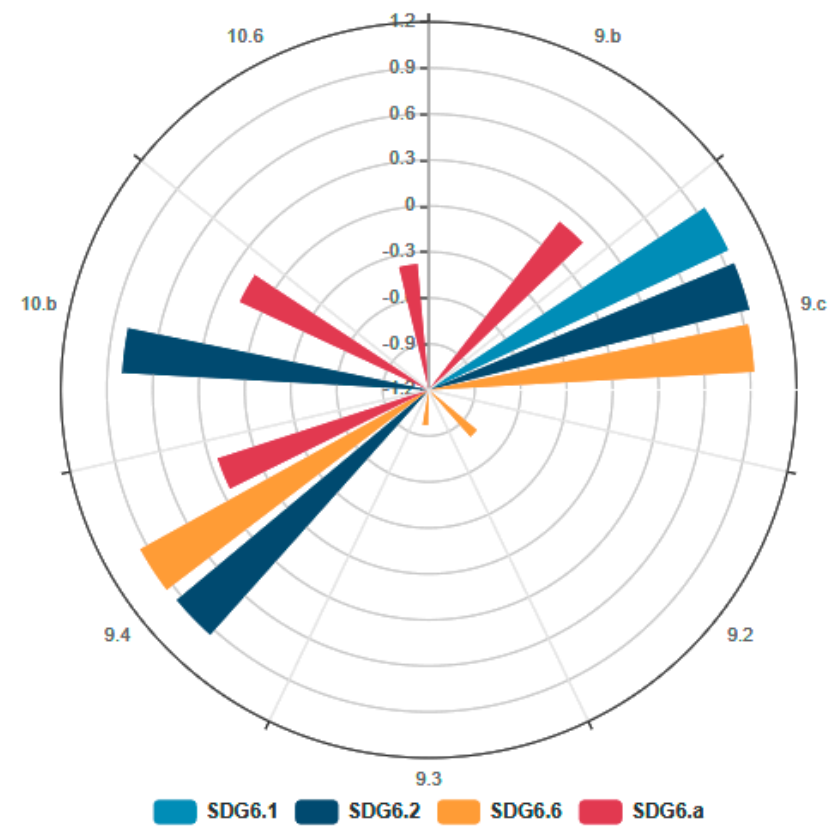

Figure 4. The relation between SDG 6 and other SDGs in Metro Manila. Source: author's elaboration.

Figure 4 presents the SDG scoreboard representing the interlinkages between the targets of SDGs 9, 10 and 6. Causal links in Figure 4 were quantified based on the correlation analysis of the country-specific time-series data of indicators corresponding to the relevant targets. The correlation coefficients, ranging between -1 and 1 , indicate a linear relationship between each pair of targets. Positive coefficients (e.g., 0.955 between SDG targets 6.1 and 9.c) represent positive linear relations, and negative ones (e.g., -0.792 between SDG targets 6.6 and 9.2) represent negative linear relations. As coefficients with larger absolute values (e.g., 0.9 with an absolute value of 0.9 ) indicate stronger linear relationships between two targets, SDG 6.1 and SDG 6.2 exhibit the strongest correlation-with SDG 9.c-among all the available interlinkages of the targets of SDG 6, 9 and 10. It also indicates that SDG targets 6.a and 10.6 exhibit the weakest linear relationship, given its smaller absolute value (e.g., -0.2 with an absolute value of 0.2). This further implies that SDG target 10.6, which is influential in the decision-making process in global international economic and financial institutions, should be improved in Metro Manila, compared to other targets to deliver more effective, credible, accountable and legitimate institutions in the region. Hereafter, the authors will analyze Metro Manila, Philippines' case by employing the methodology presented in the above section, with the use of the SDG framework as a basis. Taking Metro Manila's local context into account, the case study will be analyzed in the aspects of the environment (SDG 13), infrastructure (SDG 9), and social condition (SDG 10) synthetically, and how each of these factors relates to the water security (SDG 6) of Metro Manila.

\subsection{Case Study: Metro Manila, Philippines}

On 7 March 2019, 62 barangays (villages) in the east zone of Metro Manila had no water supply and did not receive enough warning from the government. Within a week, over 52,000 households across 200 barangays were affected. This number does not include those with low water pressure. Maynilad, which supplies water to the west side of Metro Manila, experienced no significant problems [36]. 
On the other hand, Manila Water, the private concessionaire responsible for the east zone of Metro Manila, admitted to its failure in preparing the region for a water crunch of this scale, despite being aware of the severe supply shortage. Manila Water claimed that the current water crisis is due to the El Niño event and delayed infrastructure. In addition, despite the onset of the rainy season, thousands of homes continue to experience no running water for 8-20 h daily, owing to inefficient planning and over-dependence on natural phenomena. In this section, the fundamental triggers of the water crisis and the issue are discussed from a sustainable development perspective.

\subsubsection{Environment}

While the Philippines' economy is growing rapidly, one in ten people still lack access to clean water. Although Metro Manila is the capital region of the country, it faces water shortages. Particularly, the 2019 Metro Manila water crisis that began in March 2019 demonstrated the region's proneness to water scarcity. The city faces uneven and limited water distribution. One of the reasons for the acute water shortage in Metro Manila has been identified as the increased frequency and duration of the El Niño phenomenon due to climate change. According to the World Health Organization (WHO), climate change-and its impact on the El Niño phenomenon-have exacerbated the recent increase in temperature and dried up water sources [37].

Owing to unexpectedly long periods of drought, the water levels of several dams-such as Angat Dam and La Mesa Dam—decreased, as shown in Figure 5 [38]. On 29 June 2019, the water level of Angat Dam reached a staggering low of $157.98 \mathrm{~m}$. Furthermore, it had nearly surpassed the all-time low record of $157.56 \mathrm{~m}$, as registered on 18 July 2010 [38]. This is far below its normal level of $212 \mathrm{~m}$, operational level of $180 \mathrm{~m}$, and critical level of $160 \mathrm{~m}$. While Angat Dam provides water to approximately $96 \%$ of the people in Metro Manila, this decrease in water level due to insufficient rainfall has made it difficult for Angat Dam to meet the water demands of the people living in the city. La Mesa Dam, which typically replenishes this deficit, has not been sufficient during this crisis. The water level of La Mesa Dam also reached an all-time low of 68.74 m, as of 14 March 2019, which is below its critical level of $69 \mathrm{~m}$.
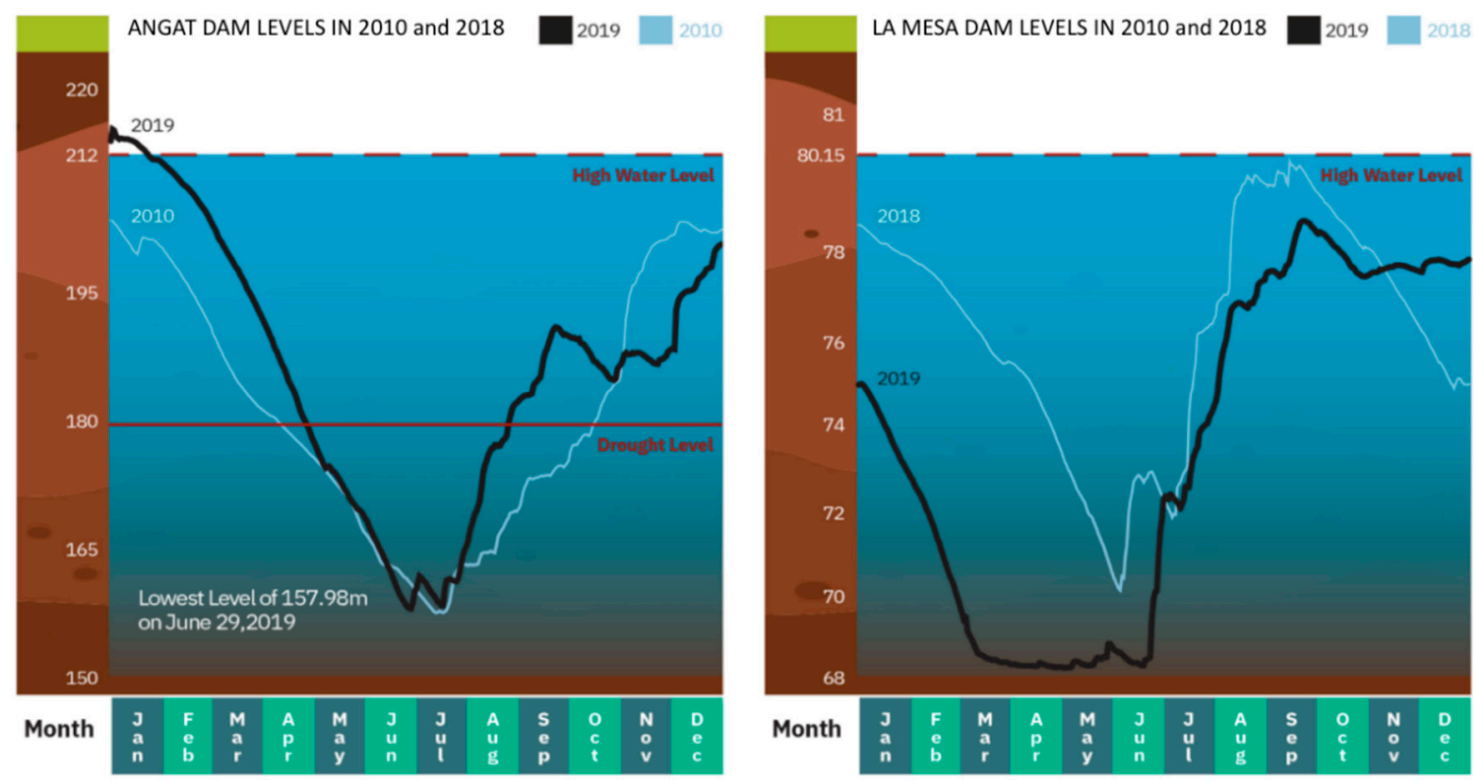

Figure 5. Angat Dam and La Mesa Dam Water Levels in 2010 and 2019, when Metro Manila saw historic lows. Source: Manila Water's special report on Water Crisis in the Manila Concession [38]. 
Climate change has impacted water security owing to its negative impact on the El Niño phenomenon. If climate change is not mitigated, it will continue to exacerbate water security. Thus, the Philippine government should focus on SDG 13 (climate action), especially by tackling SDG indicator 13.2.1, which integrates climate change measures into national policies, strategies and planning. The most effective proactive measure involves preventing the worsening of El Niño conditions, which further cements the importance of climate action in achieving sustainable water security. Although the frequency and duration of the water crisis have increased owing to climate change, the data supporting the causal relationship between climate change and the 2019 water crisis of Metro Manila are insufficient. Metro Manila is experiencing extreme water insufficiency as the La Mesa reservoir can no longer consistently offset the supply deficit during peak seasons [38]. However, other areas affected by the prolonged El Niño season-local and international-have not been affected to the same extent [39]. This suggests that the assumption that climate change is primarily responsible for the current water crisis in Metro Manila is incorrect.

In fact, Manila Water admitted that it has been aware of the coming El Niño but failed to mobilize appropriate preventative measures that could have minimized the damage currently being inflicted on Metro Manila [40]. Environmental factors may create natural conditions suitable for longer periods of drought, but proactive mechanisms can divert a calamity through the establishment of efficient infrastructure.

\subsubsection{Infrastructure}

Besides the role of environmental factors in Metro Manila's water crisis, poor sustainable infrastructure contributed to the water insecurity problems. According to the UN SDGs, economic growth, social development, and climate action are heavily dependent on investments in infrastructure, sustainable industrial development and technological progress. To develop high-quality, reliable, sustainable and resilient infrastructure, fundamental infrastructure (roads, information and communication technologies, electrical power, sanitation, and water) plays a significant role, particularly in developing countries. Padowski et al. [41] reported that urban growth and development rely on local hydrologic conditions, as well as methods for the procurement and management of water. Although freshwater resources are not accessible to all urban areas, heavy investments in large-scale hydraulic infrastructure - such as dams, aqueducts and well fields-help urban areas develop water systems for transferring, storing and regulating water resources. Thus, it helps overcome the water insecurity issues associated with urban growth and/or geographical features.

The primary source of Metro Manila's water supply is Angat Dam [42]. However, according to news reports, owing to technical limitations, Manila Water was unable to draw sufficient water from the dam even when its water level was manageable [43]. This is because the aqueducts and tunnels in Angat Dam can draw merely 4 billion L per day. The only way to address this problem is to create additional aqueducts. The Metropolitan Waterworks and Sewerage System (MWSS), the overarching agency responsible for providing water and sewerage services to all of Metro Manila and some parts of the surrounding cities, is already working on this. However, this process requires a significant amount of time. Another issue is the high level of water loss faced by Metro Manila's main concessionaires. Manila Water has denied claims regarding its leakage problem, arguing that its non-revenue water or water-loss percentage has been approximately $11 \%$ since 2010 . However, if the $31.7 \%$ water loss from Maynilad is taken into consideration (the international standard is 20\%), Metro Manila clearly has problems associated with its water infrastructure. This indicates that Metro Manila's infrastructure is vulnerable to inefficient project planning and execution.

Besides Angat Dam's technical limitation, La Mesa Dam's low water level, which reached its lowest in 12 years as of March 2019, was a problem [36]. This indicates that Manila Water can no longer depend on its emergency supply of rainwater collected from the La Mesa watershed. Furthermore, La Mesa Dam's low level does not allow it to pass through a majority of the water intake gates. Water can only pass through the lowest level of the gates, which is said to be the main inhibitor of the reservoir's 
replenishment. Eventually, this design inefficiency affected approximately 52,000 households within the east zone of Metro Manila by 7 March 2019, when Manila Water implemented operational adjustments in response to the critically low water level of the La Mesa Dam. Delays in pending projects have also affected water allocation in Metro Manila. Laguna lake was set to be a water source for Metro Manila, but inadequate designs for its Cardona water treatment plant's discharge pipe have led to significant delays. Manila Water's COO, Geodino Carpio, disclosed in a press release that "had this particular project been energized on time, we (Metro Manila) would not be facing this severe problem [40]". Such delays have occurred in other water sourcing projects in Metro Manila. Spokespersons and administrators in charge of Metro Manila's water infrastructure projects blame the issues on the delays in water infrastructure projects.

Owing to the aforementioned reasons, it can be argued that infrastructure plays a key role in improving water security. Bruns and Frick-Trzebitzky (2014) found that infrastructure mediates the flow of water resources between nature and society, and within society [44]. Moreover, infrastructure is an important factor in reducing existing inequalities; it relates closely to SDG 9, which calls for the building of resilient water-related infrastructure. According to target 9.1, high-quality, reliable, sustainable and resilient infrastructure, including regional and trans-border infrastructure, should be developed to support economic development and human well-being, with a focus on affordable and equitable access for all. Bocchini et al. (2014) argue that "resilience" combines structural analyses with social and economic aspects, and reliance on techniques for life-cycle analysis and decision-making [45]. As indicated by previous studies on resilience and infrastructure, the resilience of infrastructure depends on governance and policies. Metro Manila should adopt infrastructure policies that are supported by careful planning and efficient execution. Infrastructure designs at a community level should be implemented according to short-term and long-term needs to achieve sustainability.

\subsubsection{Social Condition}

Among the multiple factors that contributed to the Metro Manila water crisis of 2019, overpopulation may have played the biggest role. Manila City, a city within Metro Manila, was declared as the most densely populated city in the world; additionally, another six cities within the capital region were listed in the top 45 [46]. Metro Manila has experienced a boom in population over the past few decades. From having 5.93 million residents in 1980, it is home to approximately 13.08 million, as of 2018 [47]. Population growth is referred to as 'the elephant in the room' among SDGs. There is no explicit mention of tackling global population growth as a means of resolving the most critical problem of our time. Metro Manila was dubbed as the most congested city in Asia as of 2019, which is a clear indication that the region is facing a serious level of overpopulation [48]. Despite this, water sources and distribution systems are not being significantly improved to address the growing demands. In fact, Angat Dam supplies water to approximately 96\% of Metro Manila's 13 million residents. This growing population-not to mention the increasing frequency and duration of droughts caused by climate change-makes the diversification of water reservoirs vital in the coming years. The current Metro Manila water crisis is a testament to how this is no longer a future threat. When thousands of homes in Metro Manila did not receive water in March 2019, Manila Water claimed that the interruption was caused by swelling demands. As shown in Figure 6, Manila Water is capable of extracting 1600 million L per day (MLD) of water from Angat Dam, yet it demands up to 1750 MLD of water [42]. Unlike the available resources, the population continues to grow, putting the entire Metro Manila region under the threat of severe water stress. 


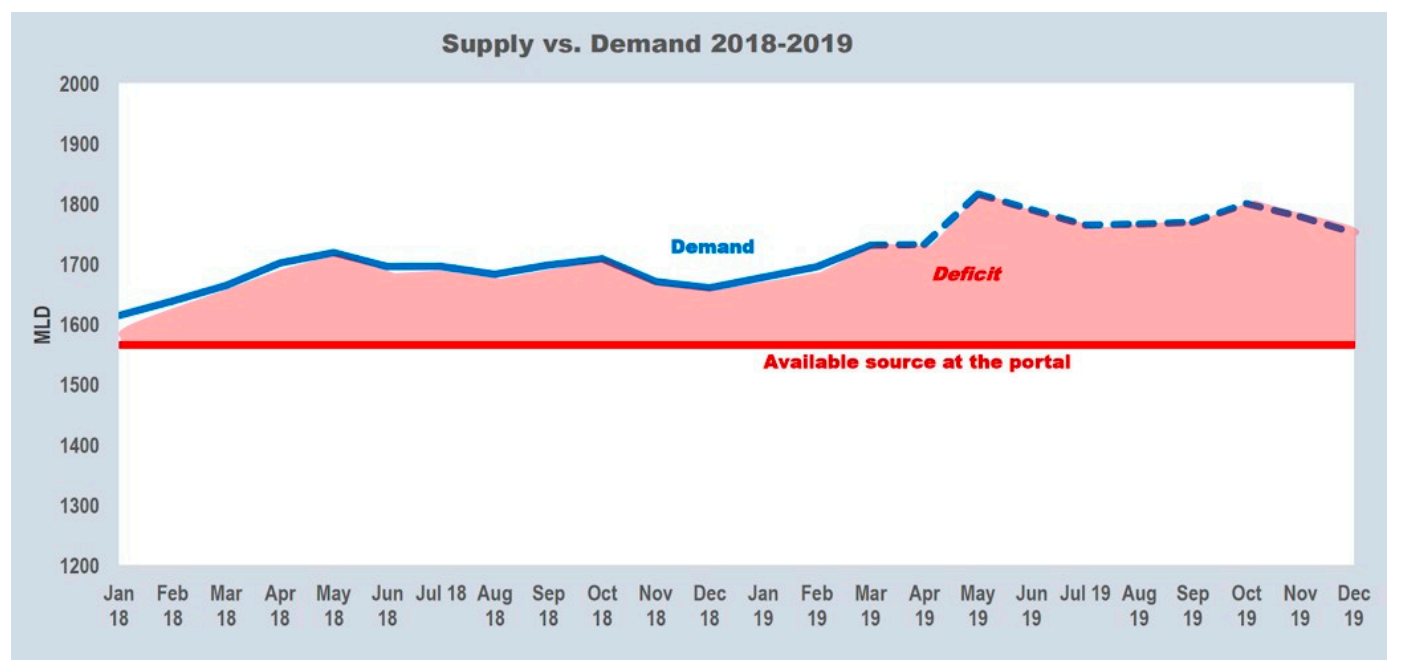

Figure 6. Manila Water's water demand and supply. Source: Manila Water [42].

Even though there is no separate SDG dedicated to population growth, the continuing growth of the population is consistently implied throughout other SDGs. Specifically, reduced inequalities (SDG 10) can be instrumental in optimizing the population and securing water security in Metro Manila. Being the capital region of the Philippines, Metro Manila offers numerous opportunities. According to target 10.4, fiscal, wage and social protection policies must be adopted to achieve better equality. Decentralizing opportunities and ensuring decent living standards across the 17 regions of the Philippines are viable solutions to address the severe congestion of Metro Manila [49]. Besides the inequalities among these regions, inequality within Metro Manila is also an issue. The Philippine government pays little attention to tackling low social mobility, which refers to the degree of mobility of individuals or groups from lower to higher socioeconomic status indicators, according to Galiani [50]. Thus, systemic flaws force the poor to stay poor. With water becoming a scarce resource, there is discrimination in the accessibility of water. This scenario is being manifested in the current water crisis of Metro Manila. Based on the information provided by Manila Water, commercial centers, tourist areas and wealthier residential areas were largely unaffected by the water crunch, whereas neglected areas experienced up to seven days of no running water [42]. Thus, water shortage was experienced in varying degrees, with the poorest suffering the most. This lack of shared concern among the entire Metro Manila region dampens the sense of urgency to resolve the water shortage crisis.

SDG 10 stresses the importance of addressing the needs of disadvantaged and marginalized populations. According to the 2017 Annual Poverty Index survey, of the top 70\% in the income stratum, $62.8 \%$ have access to clean water through a pipe in their own dwelling. However, with respect to the bottom $30 \%$, only $22 \%$ enjoy this privilege [51]. Target 10.1 aims for higher growth in incomes or expenditure per capita for the bottom $40 \%$ of the population, in comparison with the national average growth rate. The Philippines has been able to maintain this optimal dynamic in recent years, but the difference has been marginal. From 2016 to 2017, the income per capita of the bottom $30 \%$ witnessed a $12 \%$ increase, which was just slightly higher than the national average growth of $11.37 \%$ [52]. Therefore, the Philippine government must actively boost the economic growth of the poor to ensure an acceptable level of variation in access to clean water and standard of living among the different socioeconomic groups.

Metro Manila, like many rapidly urbanizing areas in Asia, is facing many social challenges that hinder the efficient distribution of basic utilities. There is little indication that the population within Metro Manila will stop growing or that the wealth inequality within the region will be alleviated soon. With these macrosocial challenges taken into account, stakeholders have the obligation to collaborate and develop alternative measures in a microsocial scale to ensure that clean water is accessible to all. However, the lack of coordination and accountability, along with the politicization of 
Metro Manila's water service system, has made the transition to sustainable water management all the more challenging to achieve.

In the 1990s, the lack of infrastructure to address the demands of a rapidly growing population caused a power and water crisis in Metro Manila. In a bid to prevent such a calamity, the Philippine Congress granted the privatization of the MWSS by passing the Water Crisis Act in 1995 [53]. MWSS awarded its 25-year concessions to Manila Water (east zone) and Maynilad Water Services (west zone) in 1997, followed by a 2009 agreement of a 15-year extension [54]. The privatization of Metro Manila's water services in 1997 brought about dramatic improvements to water service delivery. However, the 2019 water crisis of Metro Manila put this public-private partnership under serious reassessment. As the east zone of Metro Manila began experiencing water crunches on 7 March 2019, disputes within the water sector caused a delay in investigating the primary cause of the water service disruptions. Manila Water, the east zone concessionaire, claimed to have been aware of the impending water shortage months prior to 7 March. This raised concerns that Manila Water's preparations were insufficient, and that the severity of the problem had not been properly communicated to other agencies. However, Manila Water claims that the two private concessionaires have proposed several projects, including the introduction of additional water sources and water system facilities, in response to the demand projections of MWSS since 2003 [38]. MWSS released a statement that the approval and implementation of these proposed projects have been delayed, largely due to the previous board under the previous Aquino administration [55].

The politicization of the 2019 water crisis incited conflict within the water sector at a time when cooperation was needed the most. Effective coordination mechanisms are largely lacking, and existing overarching agencies lack the managerial capacity to closely monitor the activities of the private concessionaires. Despite the presence of multiple water agencies, they are neither connected vertically nor horizontally [56]. A robust national system that enables the integration of the water sector must be implemented in order to ensure proper communication and cooperation among the different agencies. This will bring about clarity for the agencies' mandates and allocate accountability for specific areas of the water system.

\subsubsection{A Summary of the Case Study}

The case study conducted in Metro Manila revealed that environmental factors in Metro Manila that negatively contribute to SDG 13 (Climate Action) require appropriate preventative measures to minimize the water shortage crisis. By tackling specific SDG 13 indicators that aim to integrate climate change measures into national policies, strategies and planning, the Philippine government should carefully consider environmental factors to prevent the worsening of El Niño conditions. This demonstrates the importance of climate action in achieving sustainable water security in Metro Manila. Additionally, as the infrastructure factors contribute to SDG 9 (Industry, Innovation, and Infrastructure), the lack of aqueducts and design inefficiencies in the major dams of Metro Manila should be overcome with careful planning and the efficient execution of policies to build a resilient water-related infrastructure. Furthermore, although there has been no separate SDG dedicated to population growth, SDG 10 can be crucial in successfully reducing inequalities not only in Metro Manila but also in other regions. These inequalities are mainly caused by systematic flaws that lead to discrimination in access to water. Overall, a holistic approach that interconnects the three related SDGs that focus on the environment, infrastructure and social conditions with SDG 6 would contribute towards developing institutional mechanisms to coordinate the actions of various actors and strengthen the complementarities and synergies of the three sectors with SDG 6.

\section{Discussion}

This study contributes to examining the linkage and role of climate change in the 2019 water crisis in Metro Manila, along with El Niño. Contrary to the first research statement, this research suggests the relatively limited role of climate change in the prevailing water crisis of Metro Manila. 
Though climate change and its subsequent impact on El Niño increases the frequency and duration of water shortages, it is difficult to conclude that $\mathrm{El} \mathrm{Niño} \mathrm{is} \mathrm{the} \mathrm{principal} \mathrm{trigger} \mathrm{of} \mathrm{the} \mathrm{current} \mathrm{water}$ crisis. This becomes more apparent when taking into account that other regions of the Philippines and other countries have not been affected by El Niño to the same extent. Instead, Metro Manila's societal features, infrastructure, disasters and DRRM play more significant roles in the crisis.

Through qualitative analysis of these factors and the utilization of the SDG scoreboard, the authors have demonstrated the interconnectivity of water security to numerous factors besides the El Niño phenomenon. In support of the second research statement, they suggest that utilizing a holistic and proactive approach to planning water systems can be sufficient in preventing water-related calamities, despite the negative impacts of climate change. The current development mechanisms of Metro Manila do not address the fundamental causes of recurring water shortages. In fact, it generates more risks by utilizing funds inefficiently to alleviate the problem. The 2019, the Metro Manila water crisis demonstrated the region's lack of capacity to address the leakage problem and manage its resources adequately. Furthermore, it is evident that their disaster warning system needs significant improvement to send out an adequate warning that can prompt effective risk minimization.

This case study demonstrates the significance of the SDG approach in achieving sustainable water security by suggesting solutions based on SDG targets and indicators, as the approach entails the development of not only water-specific strategies but also other facets, including the environment, society and infrastructure. Given that a limited number of studies have been conducted on the 2019 water crisis in Metro Manila, this study is one of the first to explore water sustainability in relation to the SDGs by specifically finding correlations between SDG 6 and the other SDG targets that represent the environment, infrastructure and social conditions of Metro Manila. By linking water security with these factors, this paper provides some clarity on their interconnectedness, and affirms the vitality of securing sustainable water systems by adopting a holistic approach.

However, some limitations must be highlighted. As this catastrophe is an ongoing phenomenon, there is insufficient quantitative data to predict the expected total damage of the water crisis and provide an in-depth analysis. By analyzing quantitative data when it becomes available, the study would be able to provide detailed strategies to resolve the prevailing water crisis.

This study highlights the major contributors to the water crisis by offering general but necessary approaches to address the root causes. By providing a holistic approach towards evaluating recurrent water crises in developing countries, especially in South East Asia, the approach can also serve as a guide to establishing efficient and sustainable strategies for possible funding agencies that have an interest in mobilizing water development projects in developing countries such as the Philippines.

\section{Conclusions}

As the Philippines moves towards economic development, it must establish objectives that align with the SDG targets. There is an urgent need to reinterpret Metro Manila's water security owing to a series of fundamental flaws in its infrastructure and society. Climate change will continue to negatively impact natural cycles; the frequency and duration of water shortages will continue to increase. While climate change mitigation is vital in the long run, adaptive proactive measures can be effective in minimizing the impacts of droughts.

This study investigated the multidisciplinary aspects of the regional development of Metro Manila based on a qualitative analysis. Future research should not only analyze Metro Manila's water security by focusing on its infrastructure, environmental and social conditions, but also consider assessing the overall outcome of regional development cases in the Philippines, thereby covering comprehensive sectors. To avoid generalization, it is also essential to understand how this study can be replicated in other regions of the Philippines, or in other countries. 
Author Contributions: Conceptualization, H.L., C.-H.L., J.S., J.H., D.J. and S.Y.; methodology, H.L. and J.S.; formal analysis, H.L., J.S. and D.J.; investigation, H.L., C.-H.L., J.S., and D.J.; writing-original draft preparation, H.L., J.S., J.H., D.J. and S.Y.; writing the manuscript of this study, H.L.; review and editing, H.L., J.S., D.J. and C.-H.L.; visualization, H.L.; supervision, C.-H.L. and W.-K.L. All authors have read and agreed to the published version of the manuscript.

Funding: This research was funded by the National Research Foundation of Korea (NRF) (Grant no. 2018K1A3A7A03089842) and the Ministry of Science and ICT, South Korea (Grant no. 2018R1A2B6005682).

Acknowledgments: The authors appreciate the financial support from the NRF, and feel gratitude to Woo-Kyun Lee and the IEETP (International Environmental Expert Training Program), which was supported by the Ministry of Environment, and Korea Environment Corporation. Special thanks to Chul-Hee Lim of Korea University for constructive feedback and comments and Joel Guenter for proofreading. We deeply feel thankful to the three anonymous reviewers for their comments and critical reading which helped improve and clarify this manuscript greatly.

Conflicts of Interest: The authors declare no conflict of interest.

\section{References}

1. UN Chronicle. Available online: https://unchronicle.un.org/article/water-sustainable-development (accessed on 3 August 2020).

2. Asian Development Bank. Asian Water Development Outlook 2016: Strengthening Water Security in Asia and the Pacific; Asian Development Bank: Mandaluyong City, Philippines, 2016.

3. Doroteo, H. Disaster Risk Profile and Disaster Risk Management Framework of the Philippines: Natural Disasters. Ph.D. Thesis, University of Oviedo, Oviedo, Spain, 2015.

4. United Nations Office for Disaster Risk Reduction. Available online: https://www.unisdr.org/files/68265_ 682308philippinesdrmstatusreport.pdf (accessed on 1 August 2020).

5. Iuchi, K.; Jibiki, Y.; Solidum, R., Jr.; Santiago, R. Natural Hazards Governance in the Philippines; Oxford Research Encyclopedia of Natural Hazard Science: Oxford, UK, 2019. [CrossRef]

6. Relief Web. Available online: https://reliefweb.int/report/philippines/rains-fall-short-manila-trickles-watercrisis (accessed on 1 August 2020).

7. Manila Bulletin. Available online: https://mb.com.ph/2019/03/12/el-nino-damage-to-agriculture-now-topsp460-million/ (accessed on 1 August 2020).

8. Rappler. Available online: https://rappler.com/voices/thought-leaders/economics-metro-manila-watershortage (accessed on 2 August 2020).

9. Detay, M.; Gaujous, D.; Hranisavljevic, D.; Olives, J.G. Consequence of El Nino 1997-98 on Manila water resources: New perspectives in water shortage management. Drought Supply Short. Manag. 1999, 18, 385-389. [CrossRef]

10. Gizaw, M.S.; Gan, T.Y. Impact of climate change and El Niño episodes on droughts in sub-Saharan Africa. Clim. Dyn. 2017, 49, 665-682. [CrossRef]

11. Tongson, E.E.; Alejo, L.A.; Balderama, O.F. Simulating impacts of El Niño and climate change on corn yield in Isabela, Philippines. Clim. Disaster Dev. J. 2017. [CrossRef]

12. Timmermann, A.; An, S.I.; Kug, J.S.; Jin, F.F.; Cai, W.; Capotondi, A.; Cobb, K.M.; Lengaigne, M.; McPhaden, M.J.; Stuecker, M.F.; et al. El Niño-southern oscillation complexity. Nature 2018, 559, 535-545. [CrossRef] [PubMed]

13. Collins, M.; An, S.I.; Cai, W.; Ganachaud, A.; Guilyardi, E.; Jin, F.F.; Jochum, M.; Lengaigne, M.; Power, S.; Timmermann, A.; et al. The impact of global warming on the tropical Pacific Ocean and El Niño. Nat. Geosci. 2010, 3, 391-397. [CrossRef]

14. Game, E.T.; Tallis, H.; Olander, L.; Alexander, S.M.; Busch, J.; Cartwright, N.; Kalies, E.L.; Masuda, Y.J.; Mupepele, A.C.; Qiu, J.; et al. Cross-discipline evidence principles for sustainability policy. Nat. Sustain. 2018, 1, 452-454. [CrossRef] [PubMed]

15. Lubchenco, J.; Barner, A.K.; Cerny-Chipman, E.B.; Reimer, J.N. Sustainability rooted in science. Nat. Geosci. 2015, 8, 741-745. [CrossRef]

16. Nerini, F.F.; Sovacool, B.; Hughes, N.; Cozzi, L.; Cosgrave, E.; Howells, M.; Tavoni, M.; Tomei, J.; Zerriffi, H.; Milligan, B. Connecting climate action with other Sustainable Development Goals. Nat. Sustain. 2019, 2, 674-680. [CrossRef] 
17. Wang, G.; Cai, W.; Gan, B.; Wu, L.; Santoso, A.; Lin, X.; Chen, Z.; McPhaden, M.J. Continued increase of extreme El Niño frequency long after $1.5^{\circ} \mathrm{C}$ warming stabilization. Nat. Clim. Chang. 2017, 7, 568-572. [CrossRef]

18. Food and Agriculture Organization of the United Nations (FAO). Understanding the Drought Impact of El Niño on the Global Agricultural Areas: An Assessment Using FAO's Agricultural Stress Index (ASI); FAO: Rome, Italy, 2014.

19. Keeble, B.R. The Brundtland report: 'Our common future'. Med. War 1988, 4, 17-25. [CrossRef]

20. United Nations Committee for Development Policy. Available online: https://sustainabledevelopment.un. org/content/documents/2754713_July_PM_2._Leaving_no_one_behind_Summary_from_UN_Committee_ for_Development_Policy.pdf (accessed on 3 August 2020).

21. Vladimirova, K. How Well Are the Links between Education and Other Sustainable Development Goals Covered in UN Flagship Reports? The United Nations Working Paper: New York, NY, USA, 2015.

22. Inter Press Service. Available online: http://www.ipsnews.net/2015/10/opinion-sanitation-water-hygiene-forall-cannot-wait-for-2030 (accessed on 5 August 2020).

23. Torres-Slimming, P.A.; Wright, C.; Carcamo, C.P.; Garcia, P.J.; IHACC Research Team; Harper, S.L. Achieving the Sustainable Development Goals: A Mixed Methods Study of Health-Related Water, Sanitation, and Hygiene (WASH) for Indigenous Shawi in the Peruvian Amazon. Int. J. Environ. Res. Public Health 2019, 16, 2429. [CrossRef] [PubMed]

24. Karnib, A. Mapping the direct and indirect interlinkages across the sustainable development goals: A qualitative nexus approach. Int. J. Dev. Sustain. 2017, 6, 1150-1158.

25. Rasul, G. Managing the food, water, and energy nexus for achieving the Sustainable Development Goals in South Asia. Environ. Dev. 2016, 18, 14-25. [CrossRef]

26. Newell, B.; Marsh, D.M.; Sharma, D. Enhancing the resilience of the Australian National Electricity Market: Taking a systems approach in policy development. Ecol. Soc. 2011, 16, 15-37. [CrossRef]

27. Centobelli, P.; Cerchione, R.; Chiaroni, D.; Del Vecchio, P.; Urbinati, A. Designing business models in circular economy: A systematic literature review and research agenda. Bus. Strategy Environ. 2020, 29, 1734-1749. [CrossRef]

28. Linnenluecke, M.K.; Birt, J.; Griffiths, A. The role of accounting in supporting adaptation to climate change. Account. Financ. 2015, 55, 607-625. [CrossRef]

29. Snyder, A. Literature review as a research methodology: An overview and guidelines. J. Bus. Res. 2019, 104, 333-339. [CrossRef]

30. Institute for Global Environmental Strategies (IGES). Available online: https://sdginterlinkages.iges.jp/ visualisationtool.html (accessed on 5 August 2020).

31. Zhou, X.; Moinuddin, M. Sustainable Development Goals Interlinkages and Network Analysis: A Practical Tool for SDG Integration and Policy Coherence; Institute for Global Environmental Strategies: Kanagawa, Japan, 2017.

32. United Nations Statistics Division. Available online: https://unstats.un.org/sdgs/report/2017/goal-06 (accessed on 5 August 2020).

33. United Nations Statistical Division. SDG Indicators: Official List of SDG Indicators. 2016. Available online: http://unstats.un.org/sdgs/indicators/indicators-list/ (accessed on 3 August 2020).

34. World Bank SDGs database. Available online: https://databank.worldbank.org/databases/sdgs (accessed on 5 August 2020).

35. Son, J.W. Impacts of Water, Sanitation, and Hygiene (WASH) Facilities on Women's Access to Education-The Case of Lao Cai Province, Vietnam. Master's Thesis, Korea University, Seoul, Korea, 2019.

36. Inquirer.net. Available online: https://newsinfo.inquirer.net/1094088/la-mesa-dam-level-hits-lowest-pointso-far-in-2019 (accessed on 5 August 2020).

37. World Health Organization. Available online: https://www.who.int/philippines/news/feature-stories/ detail/water-shortage-in-the-philippines-threatens-sustainable-development-and-health (accessed on 3 August 2020).

38. Manila Water 2019: Water Crisis in the Manila Concession. Special Reports. Available online: https: //reports.manilawater.com/2019/special-reports/water-supply-crisis (accessed on 2 August 2020).

39. Siderius, C.; Gannon, K.E.; Ndiyoi, M.; Opere, A.; Batisani, N.; Olago, D.; Pardoe, J.; Conway, D. Hydrological Response and Complex Impact Pathways of the 2015/2016 El Niño in Eastern and Southern Africa. Earth's Future 2018, 6, 2-22. [CrossRef] 
40. Philstar Global. Available online: https:/www.philstar.com/headlines/2019/03/12/1900876/el-nio-wasprojected-solutions-were-delayed-manila-water-says (accessed on 3 August 2020).

41. Padowski, J.C.; Carrera, L.; Jawitz, J.W. Overcoming Urban Water Insecurity with Infrastructure and Institutions. Water Resour. Manag. 2016, 30. [CrossRef]

42. Manila Water. Available online: https://www.manilawater.com (accessed on 5 August 2020).

43. Good Governance Philippines. Available online: http://governance.neda.gov.ph/?p=5971 (accessed on 3 August 2020).

44. Bruns, A.; Frick-Trzebitzky, F. The Global Water System in the Anthropocene. In The Notion of the Global Water Crisis and Urban Water Realities; Springer: Berlin, Germany, 2014; pp. 415-426. [CrossRef]

45. Bocchini, P.; Frangopol, D.M.; Ummenhofer, T.; Zinke, T. Resilience and Sustainability of Civil Infrastructure: Toward a Unified Approach. J. Infrastruct. Syst. 2014, 20. [CrossRef]

46. United Nations Department of Economic and Social Affairs Population Dynamics. Available online: https:// www.un.org/en/development/desa/population/publications/database/index.asp (accessed on 2 August 2020).

47. Philippine Statistics Authority. Available online: https://psa.gov.ph/content/quickstat-national-capitalregion-june-2018 (accessed on 3 August 2020).

48. Asian Development Bank. Asian Development Outlook 2019 Update: Fostering Growth and Inclusion in Asia's Cities; Asian Development Bank: Mandaluyong City, Philippines, 2019.

49. World Bank Group. Philippines Urbanization Review: Fostering Competitive, Sustainable and Inclusive Cities; The World Bank: Washington, DC, USA, 2017.

50. Galiani, S. Social Mobility: What Is It and Why Does It Matter? SSRN Electron. J. 2008. [CrossRef]

51. Bersales, L.G.S. Annual Poverty Indicators Survey Final Report 2017; Philippine Statistics Authority: Quezon City, Philippines, 2018.

52. Bersales, L.G.S. Families with Electricity in House/Building They Reside in and Families by Main Source of Water Supply by Income Stratum; Philippine Statistics Authority: Quezon City, Philippines, 2018.

53. National Water Crisis Act. 1995. (Republic Act No. 8041 of 1995). Available online: https://www.chanrobles. com/republicactno8041.htm\#.Xyq5d_gzaL8 (accessed on 5 August 2020).

54. MWSS Concession Agreement. 1997; (Republic Act No. 6234). Available online: http://ro.mwss.gov.ph/wpcontent/uploads/2013/02/CA-MWCI.pdf (accessed on 2 August 2020).

55. Metropolitan Waterworks and Sewerage System. Available online: http://mwss.gov.ph/mwss-penalizesmanila-water-with-p1-15-b-fine/ (accessed on 5 August 2020).

56. Rola, A.C.; Pulhin, J.M.; Tabios, G.Q.; Lizada, J.C.; Dayo, M.H.F. Challenges of Water Governance in the Philippines. Philipp. J. Sci. 2015, 144, 197-208. 